Article

\title{
Cyclic Sequential Removal of Alizarin Red S Dye and Cr(VI) Ions Using Wool as a Low-Cost Adsorbent
}

\author{
Mustafa I. Khamis ${ }^{1}$, Taleb H. Ibrahim ${ }^{2, *}$, Fawwaz H. Jumean ${ }^{1}$, Ziad A. Sara ${ }^{1}$ and \\ Baraa A. Atallah 1 \\ 1 Department of Biology, Chemistry and Environmental Sciences, American University of Sharjah, \\ Sharjah 26666, UAE; mkhamis@aus.edu (M.I.K.); fjumean@aus.edu (F.H.J.); ziyadsara@gmail.com (Z.A.S.); \\ batallah@aus.edu (B.A.A.) \\ 2 Department of Chemical Engineering, American University of Sharjah, Sharjah 26666, UAE \\ * Correspondence: italeb@aus.edu; Tel.: +971-507769239
}

Received: 22 April 2020; Accepted: 5 May 2020; Published: 9 May 2020

check for updates

\begin{abstract}
Alizarin red S (ARS) removal from wastewater using sheep wool as adsorbent was investigated. The influence of contact time, $\mathrm{pH}$, adsorbent dosage, initial ARS concentration and temperature was studied. Optimum values were: $\mathrm{pH}=2.0$, contact time $=90 \mathrm{~min}$, adsorbent dosage $=8.0 \mathrm{~g} / \mathrm{L}$. Removal of ARS under these conditions was $93.2 \%$. Adsorption data at $25.0{ }^{\circ} \mathrm{C}$ and 90 min contact time were fitted to the Freundlich and Langmuir isotherms. R2 values were 0.9943 and 0.9662, respectively. Raising the temperature to $50.0^{\circ} \mathrm{C}$ had no effect on ARS removal. Free wool and wool loaded with ARS were characterized by Fourier Transform Infrared Spectroscopy (FTIR). ARS loaded wool was used as adsorbent for removal of $\mathrm{Cr}(\mathrm{VI})$ from industrial wastewater. ARS adsorbed on wool underwent oxidation, accompanied by a simultaneous reduction of $\mathrm{Cr}$ (VI) to $\mathrm{Cr}$ (III). The results hold promise for wool as adsorbent of organic pollutants from wastewater, in addition to substantial self-regeneration through reduction of toxic $\mathrm{Cr}(\mathrm{VI})$ to $\mathrm{Cr}(\mathrm{III})$. Sequential batch reactor studies involving three cycles showed no significant decline in removal efficiencies of both chromium and ARS.
\end{abstract}

Keywords: Alizarin Red S; wool; adsorption isotherms; dyes; chromium; cyclic process

\section{Introduction}

Large amounts of dye-contaminated wastewaters are released yearly from leather, cosmetics, as well as the pharmaceutical, plastics and textile industries. Most of these dyes are skin irritants, mutagenic or carcinogenic [1,2]. Dye-polluted water decreases photosynthesis since light penetration is inhibited [3]. These dyes have complex aromatic structures, which give them thermal, optical and physicochemical stability, and thus, they could not be easily biodegraded by natural substances [4-6]. Alizarin red S (ARS) (Figure 1), or 1,2-dihydroxy-9,10-anthra-quinonesulfonic acid sodium salt, is a water soluble anthraquinone dye originally derived from the root of the madder plant [7]. It has been extensively employed since ancient times in dyeing textiles [8]. It is a strong oxidizing agent, and hence, must be stored away from moisture and heat [9]. 


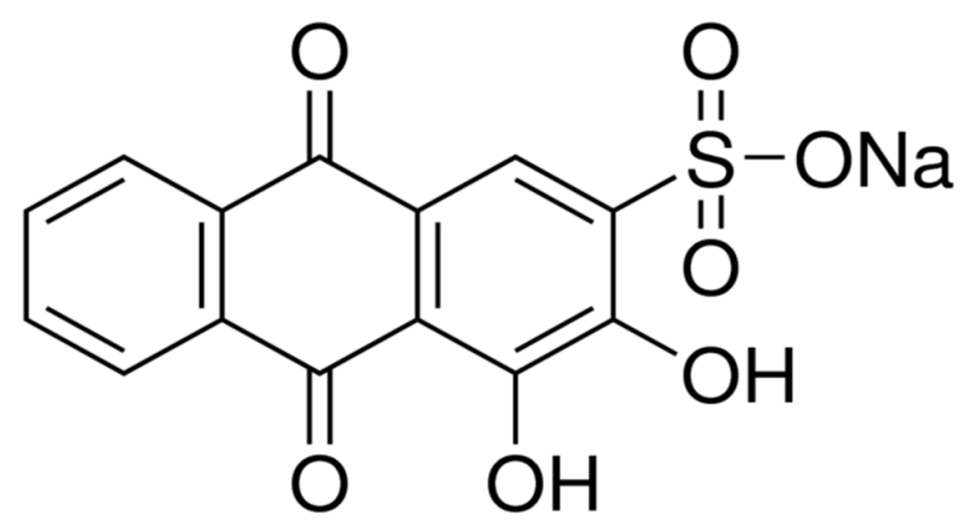

Figure 1. Alizarin red S (ARS).

A wide range of physical and chemical treatment technologies have been investigated for removing dyes from wastewater. They include coagulation, precipitation, adsorption, membrane filtration, electrochemical techniques and ozonation [10]. Among these, adsorption is the most widely employed, due to its high efficiency, non-toxicity, readily available adsorbents, low cost, ease of recovery and environmental sustainability [11-13]. Applicability largely depends on the cost and efficiency of adsorbent. Currently, various potential adsorbents are used for removal of specific organic compounds from wastewater. The adsorption of dyes transfers them from water effluent to solid phase, thereby decreasing effluent volume. Native mustard husk has been used in ARS removal from aqueous solutions, with thermodynamic studies indicating that the process is spontaneous and endothermic [14]. Pentaerythritol modified multi-walled carbon nanotubes (ox-MWCNT-PER) has been shown to be highly efficient in ARS removal [15]. Removal of ARS from wastewater using alumina as adsorbent has been investigated at optimum conditions [16]. Moreover, activated carbon is a good adsorbent for removal of ARS from wastewater, as indicated by favorable thermodynamic parameters [17].

Heavy metals, including chromium, are widely distributed in the environment as a result of numerous industrial applications. These include electroplating, chromate manufacture, wood preservation, galvanization, steel industry, paint, textile production, oxidative dyeing, cooling water towers, leather tanning, corrosion inhibitors and batteries [18]. As a result, heavy metals are found in many industrial wastewaters [19-21]. Chromium is a metallic element listed by the Environmental Protection Agency (EPA) as one of 129 priority pollutants [22,23]. It is found in the air, water and soil, and occurs in several oxidation states ranging from $\mathrm{Cr}(\mathrm{II})$ to $\mathrm{Cr}(\mathrm{VI})$, with the trivalent and hexavalent states being the most stable and common [1-3]. In natural waters, chromium is present in several forms, the most common of which are $\mathrm{Cr}(0), \mathrm{Cr}(\mathrm{III})$, and $\mathrm{Cr}(\mathrm{VI})$. $\mathrm{Cr}(\mathrm{III})$ has very low solubility and is relatively stable, whereas $\mathrm{Cr}(\mathrm{VI})$ is environmentally mobile and highly toxic. Exposure to $\mathrm{Cr}(\mathrm{VI})$ causes various health problems, including skin and stomach irritation, dermatitis, liver damage, kidney circulation and nerve and tissue damage [24-26]. Numerous technologies have already been applied in the removal of $\mathrm{Cr}(\mathrm{VI})$ from aqueous solutions. These include adsorption, biosorption, ion-exchange, foam flotation, electrolysis, surface adsorption precipitation, reverse osmosis, sand filtration, chemical reduction/oxidation, electrochemical precipitation, membrane filtration and solvent extraction [27-30].

In previous studies by our group, sheep wool has been found to be efficient in $\mathrm{Cr}(\mathrm{VI})$ removal, with subsequent reduction to $\mathrm{Cr}$ (III) [31,32]. This study reports on the results of using sheep wool for the removal of ARS from wastewater and the possibility of regenerating the contaminated wool. The outcome of the research could be utilized in a sequential batch reactor for removal of the two pollutants from wastewaters. 


\section{Materials and Methods}

\subsection{Materials}

All chemicals were of analytical grade and used without further purification. Solutions were prepared using distilled deionized water (DDW) and their concentrations determined spectrophotometrically. ARS was from BDH (Turkey). Potassium dichromate was from Riedel De-Haen (Germany). Acetone and 5-di-phenyl carbazide were from Sigma Aldrich (USA). Sheep wool (Sharjah animal market) was trimmed and riffled, then washed with water and detergent for two days.

\subsection{Instrumentation}

ARS and $\mathrm{Cr}(\mathrm{VI})$ concentrations were determined spectrophotometrically using Cary 50 (Varian, Australia). Total chromium was determined using Spectra AA220FS (Varian, Australia). Samples were shaken using Edmund Buhler shaker (KS-15/TH-15, Bodelshausen, Germany) at $25.0 \pm 0.1^{\circ} \mathrm{C}$. pH was measured on a Thermo-Orion 210A $+\mathrm{pH}$ meter (USA) equipped with a combined glass electrode. IR spectra were obtained on a Spectrum One FTIR (Perkin Elmer, Waltham, MA, USA). ARS oxidation byproducts were detected using HPLC (Shimadzu, LC-2040C, Kyoto, Japan).

\subsection{Methods}

\subsubsection{Reagent Preparation}

A $1000 \mathrm{mg} / \mathrm{L}$ stock ARS solution was prepared at $\mathrm{pH} 2.0$ and used to prepare standard solutions in the range 1-20 mg/L. Stock solutions containing $1000 \mathrm{mg} / \mathrm{L} \mathrm{Cr}(\mathrm{VI})$ were prepared by dissolving potassium dichromate in DDW. Stock ligand solutions were prepared by mixing $0.20 \mathrm{~mL}$ of $0.05 \%$ of 1,5 diphenyl carbazide (in acetone) with 2 drops of $6.0 \mathrm{M}$ sulfuric acid and $0.10 \mathrm{~mL}$ of sample. Standard $\mathrm{Cr}(\mathrm{VI})$ solutions were in the range $1-10 \mathrm{mg} / \mathrm{L}$.

\subsubsection{Determination of $\mathrm{Cr}$ ions Concentration}

Total $\mathrm{Cr}$ concentration was determined by atomic absorption spectroscopy (AAS). The 1,5-diphenyl carbazide method could not be used in the determination of $\mathrm{Cr}(\mathrm{VI})$ alone, because $\mathrm{Cr}(\mathrm{VI})$ removal by wool-ARS complex was accompanied by formation of ARS oxidation by-products. ARS degradation by oxidation involves the cleavage of dye-chromophore components [33,34]. FTIR analysis of residual products from dye oxidation gave IR bands at 1717, 1623, 1387, 1105 and $1045 \mathrm{~cm}^{-1}$, attributed to $>\mathrm{C}=\mathrm{O}$ (carbonyl), $>\mathrm{C}=\mathrm{C}<$ (alkenes), $-\mathrm{C}-\mathrm{C}-\mathrm{C}$ (alkanes), $\mathrm{SO}_{4}{ }^{2-}$ and $-\mathrm{C}-\mathrm{O}-\mathrm{C}$ - groups, respectively. These by-products interfere with analysis of $\mathrm{Cr}(\mathrm{VI})$ by 1,5-diphenyl carbazide. Hence, only total $\mathrm{Cr}$ could be analyzed by AAS. The highest removal of $\mathrm{Cr}(\mathrm{VI})$ was $93 \%$, as detected by AAS. However, previous studies by our group revealed that, at this short term contact, slight amounts of $\mathrm{Cr}$ (III) were released into solution [31]. This process causes incomplete removal of $\mathrm{Cr}(\mathrm{VI})$.

\subsubsection{Adsorption Studies}

Batch adsorption studies were carried out in flasks containing $50 \mathrm{~mL}$ of test solutions at the desired initial ARS concentrations. $\lambda_{\max }$ for dye solutions was $261 \mathrm{~nm}$. Batch adsorption studies were then carried out. Wool loaded with ARS was placed in flasks containing the desired initial $\mathrm{Cr}(\mathrm{VI})$ concentration and the contents shaken. Shaking conditions were: $1.5 \mathrm{~h}, 25.0^{\circ} \mathrm{C}$ and $175 \mathrm{rpm}$. AAS was used to measure total $\mathrm{Cr}$ concentrations. Oxidation by-products of ARS by $\mathrm{Cr}(\mathrm{VI})$ were detected using HPLC under the following conditions: mobile phase 40:60\% methanol:phosphate buffer, Pinnacle D8 C8 $5 \mu \mathrm{m}$ (RESTEK, Bellefonte, PA, USA), analytical wavelength $540 \mathrm{~nm}$ and $1.5 \mathrm{~mL} / \mathrm{min}$ flow rate.

\subsubsection{Regeneration In-Place Studies}

Wool loaded with ARS was prepared by shaking wool with $100 \mathrm{mg} / \mathrm{L}$ ARS solution at optimum conditions. The resulting wool-ARS was washed with DDW and dried. The remaining ARS solution 
was analyzed spectrophotometrically. ARS removal was $88 \%$. Wool-ARS was shaken with $50 \mathrm{mg} / \mathrm{L}$ $\mathrm{Cr}(\mathrm{VI})$ solution at optimum conditions for 4 days. Subsequently, the wool-ARS-Cr was collected, washed with DDW and dried. The remaining $\mathrm{Cr}(\mathrm{VI})$ solution was analyzed by AAS, giving a removal efficiency of $86.8 \%$. The cycle was repeated three times.

\section{Results and Discussion}

\subsection{Adsorption Studies}

Removal of ARS was calculated using

$$
\% \text { Removal }=\left(\left(C_{o}-C_{e}\right) / C_{o}\right) * 100
$$

where $C_{o}$ and $C_{e}$ are initial and equilibrium ARS concentrations $(\mathrm{mg} / \mathrm{L})$, respectively.

\subsubsection{Optimization Studies on ARS Removal by Wool}

\section{Effect of Contact Time}

Figure 2 shows the effect of contact time on ARS removal. At all three $\mathrm{pH}$ values used, removal increases with increasing contact time until a maximum is reached at ca. $90 \mathrm{~min}$, selected as the optimum time.

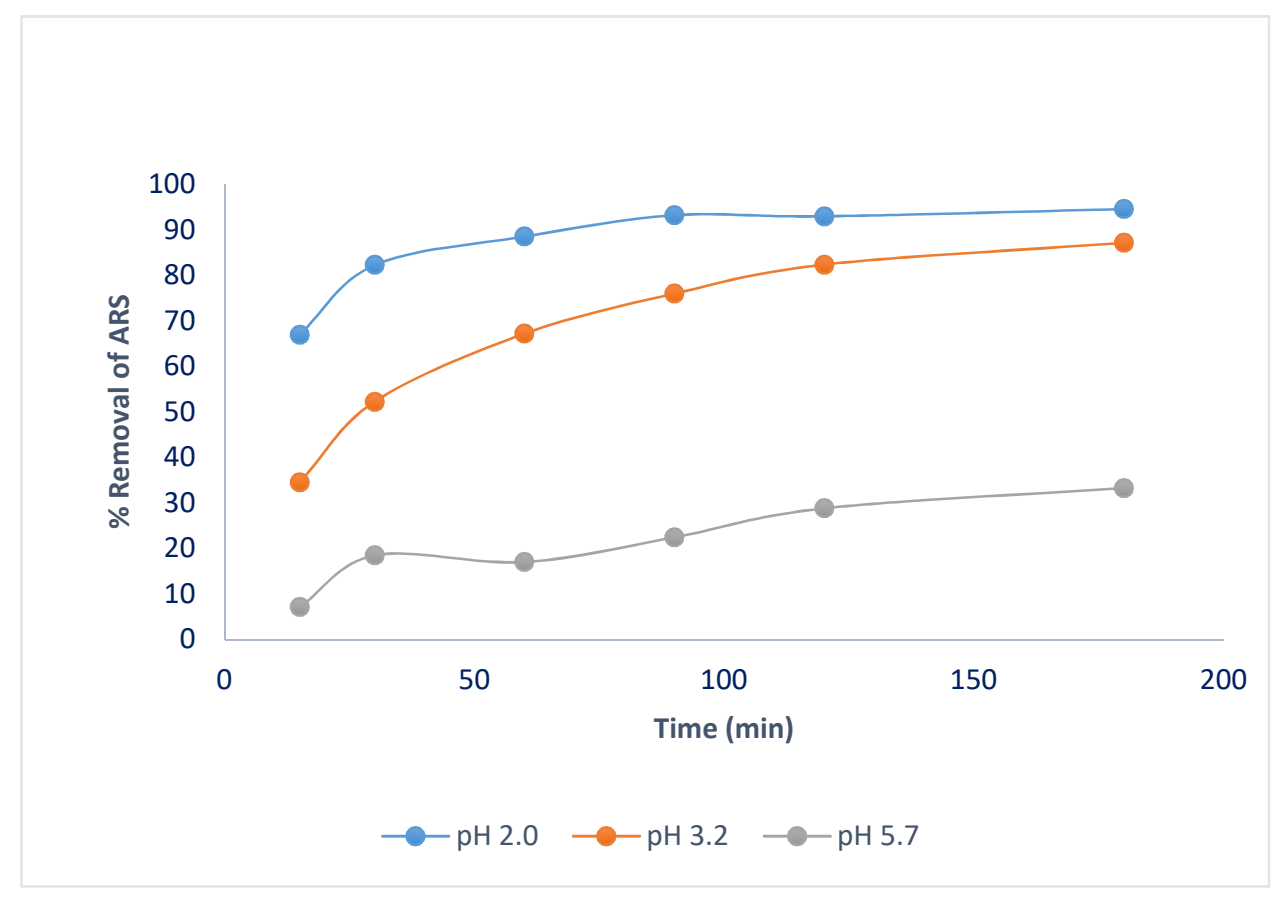

Figure 2. Effect of contact time on ARS removal. Adsorbent dosage $=8.0 \mathrm{~g} / \mathrm{L}, \mathrm{T}=25.0{ }^{\circ} \mathrm{C}$, shaking speed $=175 \mathrm{rpm}$.

\section{Effect of $\mathrm{pH}$}

ARS is employed as an indicator in acid-base titration, and changes color in the $\mathrm{pH}$ range 4.0 (yellow)-6.0 (red) [35]. At $\mathrm{pH}<4.6$, the acidic form predominates, whereas at $\mathrm{pH}>6.0$, it is mostly in the the basic form. Figure 3 shows the effect of $\mathrm{pH}$ on ARS removal. As $\mathrm{pH}$ increases, removal decreases from $90 \%$ at $\mathrm{pH} 2.0$ reaching a minimum of $<20 \%$ at $\mathrm{pH}>5.0$. Hence the acidic form ARS is the one more favorably adsorbed by wool. $\mathrm{pH} 2.0$ was thus selected as optimum in subsequent measurements. 


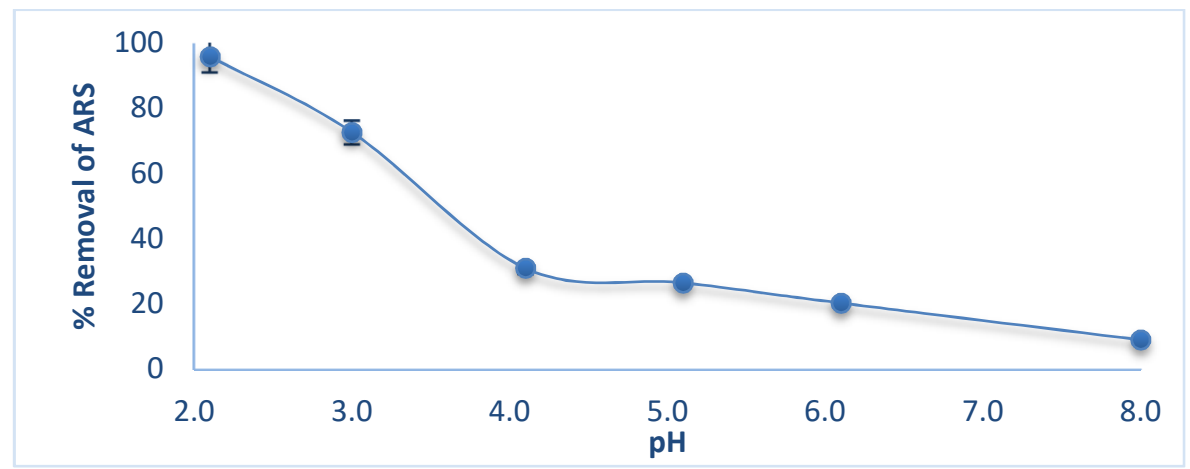

Figure 3. Effect of $\mathrm{pH}$ on ARS removal by wool. Adsorbent dosage $=8.0 \mathrm{~g} / \mathrm{L}$, initial $[$ ALS $]=100 \mathrm{mg} / \mathrm{L}$, $\mathrm{T}=25.0^{\circ} \mathrm{C}$, contact time $=90 \mathrm{~min}$, shaking speed $=175 \mathrm{rpm}$.

\section{Effect of Wool Dosage}

Figure 4 shows the effect of wool dosage on ARS removal at optimum conditions. ARS removal increases with increasing wool dosage until a maximum $8.0 \mathrm{~g} / \mathrm{L}$. This dosage was selected as optimal and used in further experiments.

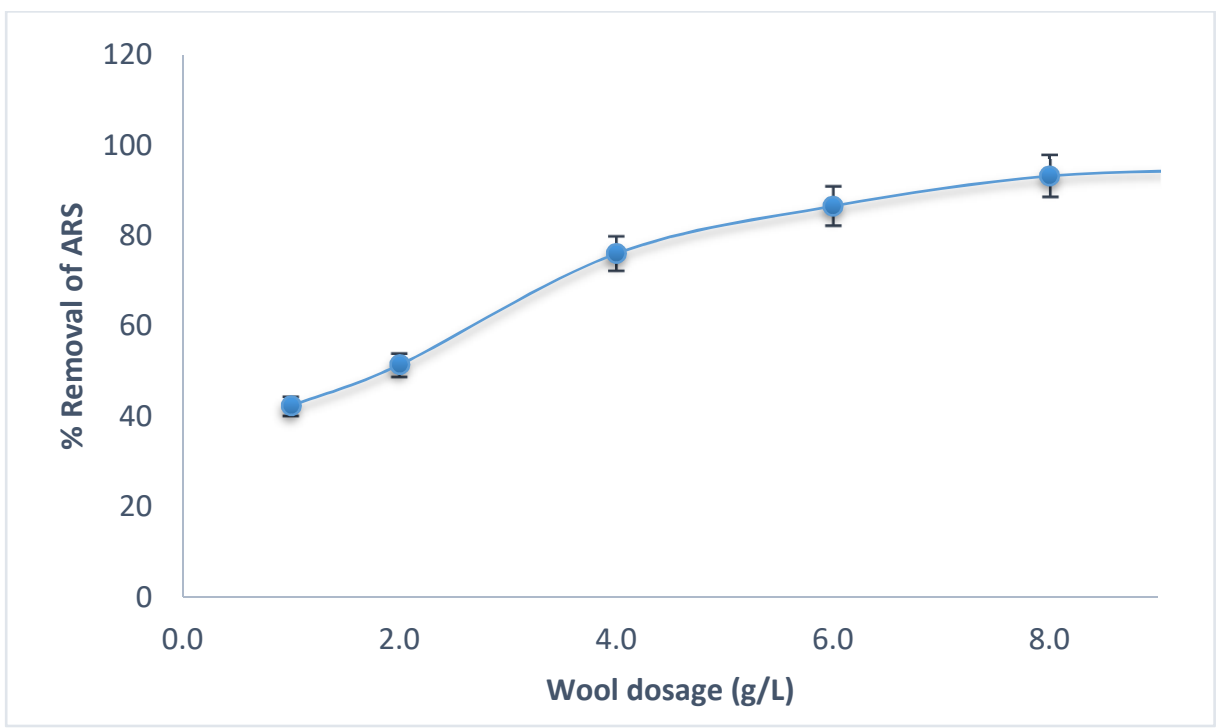

Figure 4. Effect of adsorbent dosage on removal of ARS by wool at different wool dosages. Initial $[$ ARS $]=100 \mathrm{mg} / \mathrm{L}, \mathrm{pH}=2.0$, contact time $=90 \mathrm{~min}, \mathrm{~T}=25.0^{\circ} \mathrm{C}$, shaking speed $=175 \mathrm{rpm}$.

Effect of Temperature

For initial ARS concentrations of $60 \mathrm{mg} / \mathrm{L}, 80 \mathrm{mg} / \mathrm{L}$ and $100 \mathrm{mg} / \mathrm{L}$, increasing the temperature from 25.0 to $50.0^{\circ} \mathrm{C}$ has little effect on ARS removal (Figure 5). The temperature of $25.0^{\circ} \mathrm{C}$ was selected as optimal in adsorption isotherms. 


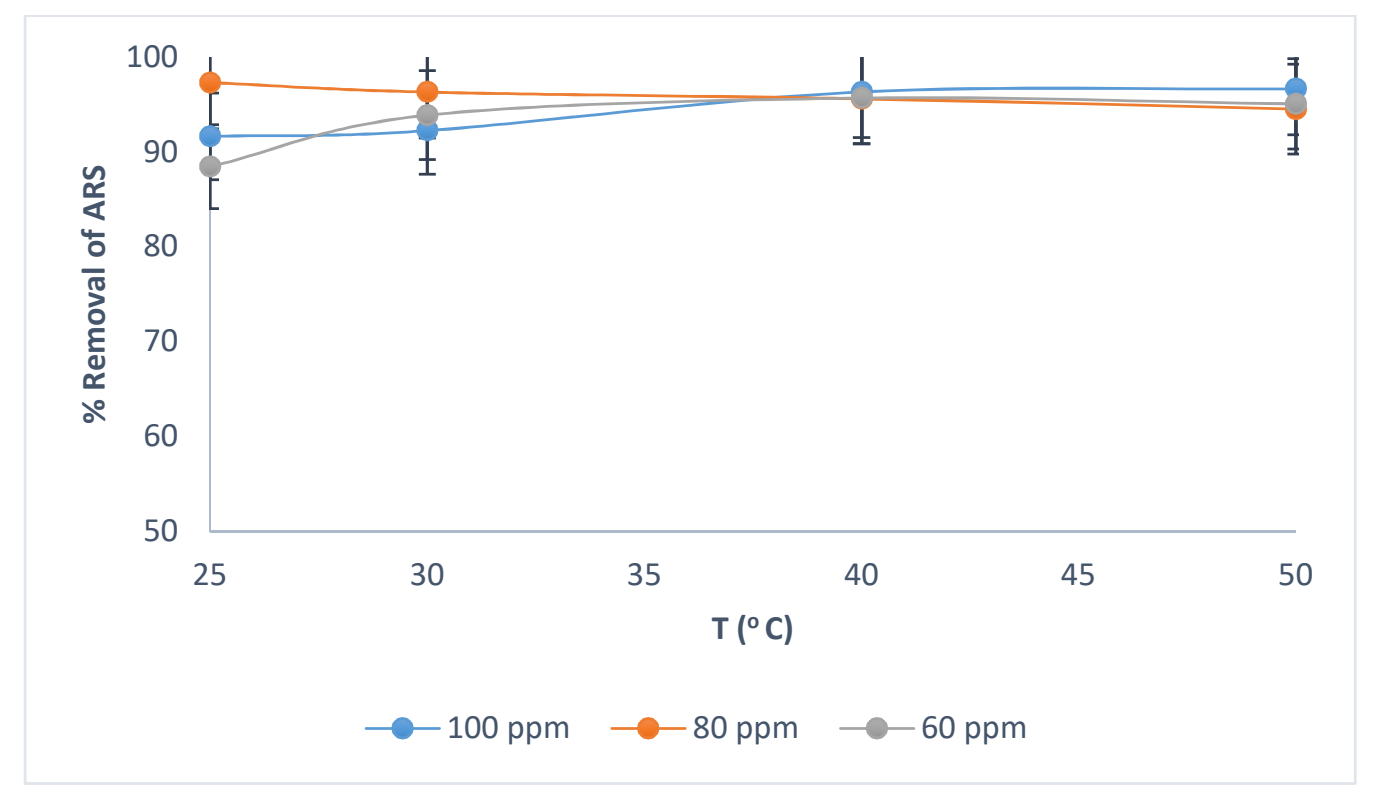

Figure 5. Effect of temperature and initial ARS concentration on removal of ARS by wool. Adsorbent dosage $=8.0 \mathrm{~g} / \mathrm{L}$, contact time $=90 \mathrm{~min}, \mathrm{pH}=2.0$, shaking speed $=175 \mathrm{rpm}$.

\subsubsection{Adsorption Isotherms}

The adsorption capacity $\left(\mathrm{q}_{\mathrm{e}}\right)$ for ARS removal was evaluated using

$$
\mathrm{q}_{\mathrm{e}}=\left(\mathrm{C}_{\mathrm{o}}-\mathrm{C}_{\mathrm{e}}\right) \times V / m
$$

where $\mathrm{q}_{\mathrm{e}}$ is the equilibrium adsorption capacity (mg adsorbate/g adsorbent), $V$ is the volume of solution (L) and $m$ is the mass of adsorbent (g). At optimum adsorption parameters, $\mathrm{q}_{\mathrm{e}}$ was evaluated at several initial concentrations and the results fitted to the linearized forms of the Langmuir (Equation (3)) and Freundlich (Equation (4)) isotherms [36]. These are

$$
\begin{aligned}
\mathrm{Ce} / \mathrm{q}_{\mathrm{e}} & =1 / \mathrm{Qb}+\mathrm{C}_{\mathrm{e}} / \mathrm{Q} \\
\mathrm{q}_{\mathrm{e}} & =\mathrm{K}_{\mathrm{f}} \mathrm{C}_{\mathrm{e}}^{1 / n}
\end{aligned}
$$

where $C_{e}$ is the equilibrium concentration $(\mathrm{mg} / \mathrm{L}), \mathrm{q}_{\mathrm{e}}$ is the amount adsorbed at equilibrium, in $\mathrm{mg} / \mathrm{g}$ adsorbent, $\mathrm{Q}(\mathrm{mg} / \mathrm{g})$ and $\mathrm{b}(\mathrm{L} / \mathrm{mg})$ are the Langmuir constants, representing adsorption capacity and energy, respectively. $K_{f}$ and $n$ are the Freundlich constants. The poor fit to the Langmuir isotherm in Figure 6a indicates that adsorption does not follow this isotherm. This may be attributed to the nonequivalence adsorption sites on wool. Figure $6 \mathrm{~b}$ shows the data fitted to the Freundlich isotherm. The good linearity of this plot clearly reveal that adsorption best fits the Freundlich isotherm, indicating that adsorption sites are not equivalent. The Freundlich constants, $\mathrm{K}_{\mathrm{f}}$ and $\mathrm{n}$, were 3.38 and 1.70, respectively. 


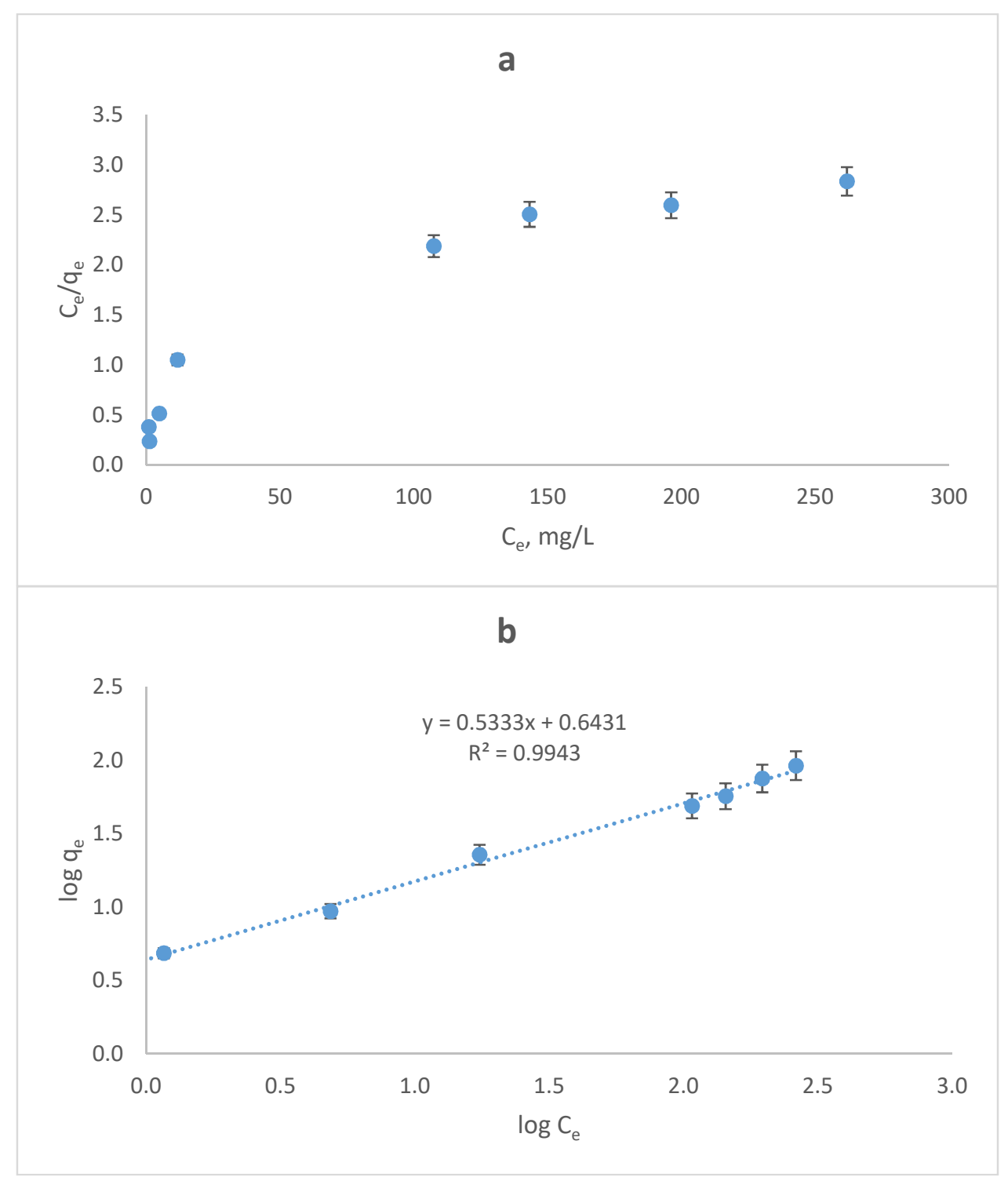

Figure 6. (a) Langmuir and (b) Freundlich plots for adsorption of ARS by wool. Adsorbent dosage = $8.0 \mathrm{~g} / \mathrm{L}, \mathrm{T}=25.0^{\circ} \mathrm{C}$, contact time $=90 \mathrm{~min}, \mathrm{pH}=2.0$, shaking speed $=175 \mathrm{rpm}$.

\subsubsection{Adsorption Kinetics}

The kinetics of adsorption of ARS by wool was studies at $\mathrm{pH} 2$ and were fitted to both Lagergren pseudo first order model (Equation (5)) and pseudo second order model (Equation (6)) [37,38].

$$
\begin{gathered}
\ln \left(q_{e}-q_{t}\right)=\ln q_{e}-k t \\
\frac{t}{q_{t}}=\frac{1}{k_{2} q_{e}^{2}}+\frac{t}{q_{e}}
\end{gathered}
$$

Our data was found to best fit the pseudo second order model with $R^{2}=1$ yielding a value for the second order rate constant $\left(k_{2}\right)$ of $0.134 \mathrm{~g} \mathrm{mg}^{-1} \mathrm{~min}^{-1}$ at $25.0^{\circ} \mathrm{C}$. 


\subsection{Removal of ARS by Wool and by Wool Loaded with Cr(VI)}

\subsubsection{FTIR Spectra}

An earlier publication by our group reported on Electron dispersive X-ray spectroscopy (EDS) and FTIR characterization of wool and wool loaded with $\mathrm{Cr}$ (VI) [31]. IR spectra of ARS were subsequently reported [33]. In this work, FTIR was used to monitor removal of ARS by wool, In Figure 7a, the peak at $3459 \mathrm{~cm}^{-1}$ is due to the $-\mathrm{OH}$ group, whereas peaks at $3094 \mathrm{~cm}^{-1}$ and $2926 \mathrm{~cm}^{-1}$ arise from $=\mathrm{C}-\mathrm{H}$ groups in aromatic rings. Peaks at $2400 \mathrm{~cm}^{-1}, 1666 \mathrm{~cm}^{-1}, 1634 \mathrm{~cm}^{-1}$ and $1588 \mathrm{~cm}^{-1}$ are characteristic of anthraquinone molecules, whereas those at $1155 \mathrm{~cm}^{-1}$ and $728 \mathrm{~cm}^{-1}$ are for sulfonate groups. Figure $7 \mathrm{~b}$ shows spectra of free wool with features described earlier [31]. Upon complexation with ARS, changes were observed (Figure 7c). Specifically, the broad peak at $4000-2800 \mathrm{~cm}^{-1}$ is sharpened, and a new band at $2400 \mathrm{~cm}^{-1}$ appears. Changes in the broad peak between $1600-800 \mathrm{~cm}^{-1}$ are also observed. These changes indicate that ARS is essentially taken up by wool. Adsorption of $\mathrm{Cr}(\mathrm{VI})$ by wool loaded with ARS results in further FTIR changes (Figure 7d), primarily in the $1200-800 \mathrm{~cm}^{-1}$ range. This observation indicates that ARS on wool undergoes oxidation by $\mathrm{Cr}(\mathrm{VI})$ to form aromatic byproducts.

(a)

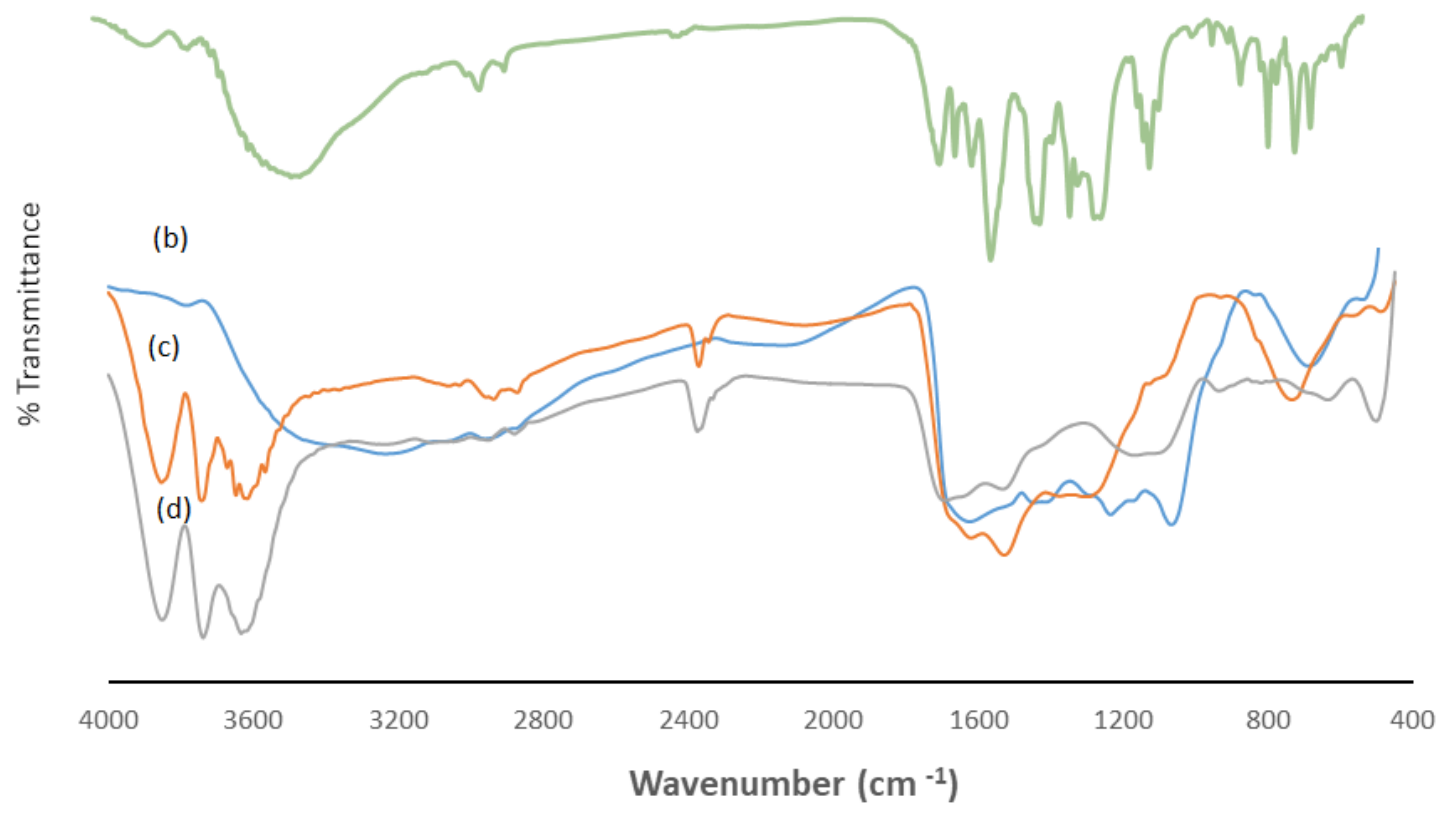

Figure 7. FTIR spectra of (a) ARS, (b) free wool, (c) wool-ARS, (d) wool-ARS loaded with Cr(VI).

\subsubsection{Oxidation Byproducts}

Upon adsorption of $\mathrm{Cr}(\mathrm{VI})$ by wool loaded with ARS, oxidation by-products of ARS were formed (Figure 8), indicating that adsorbed $\mathrm{Cr}(\mathrm{VI})$ undergoes reduction to $\mathrm{Cr}$ (III). These by-products interfere with spectrophotometric determination of $\mathrm{Cr}(\mathrm{VI})$, with the result that concentrations of individual $\mathrm{Cr}$ species could not be determined. AAS, which gives total $\mathrm{Cr}$, was hence used to follow the uptake of $\mathrm{Cr}(\mathrm{VI})$ by wool-ARS using short term contact time, so that $\mathrm{Cr}(\mathrm{III})$ has minimum interference [31]. The effect of contact time, $\mathrm{pH}$, dosage and temperature were studied and optimized. 


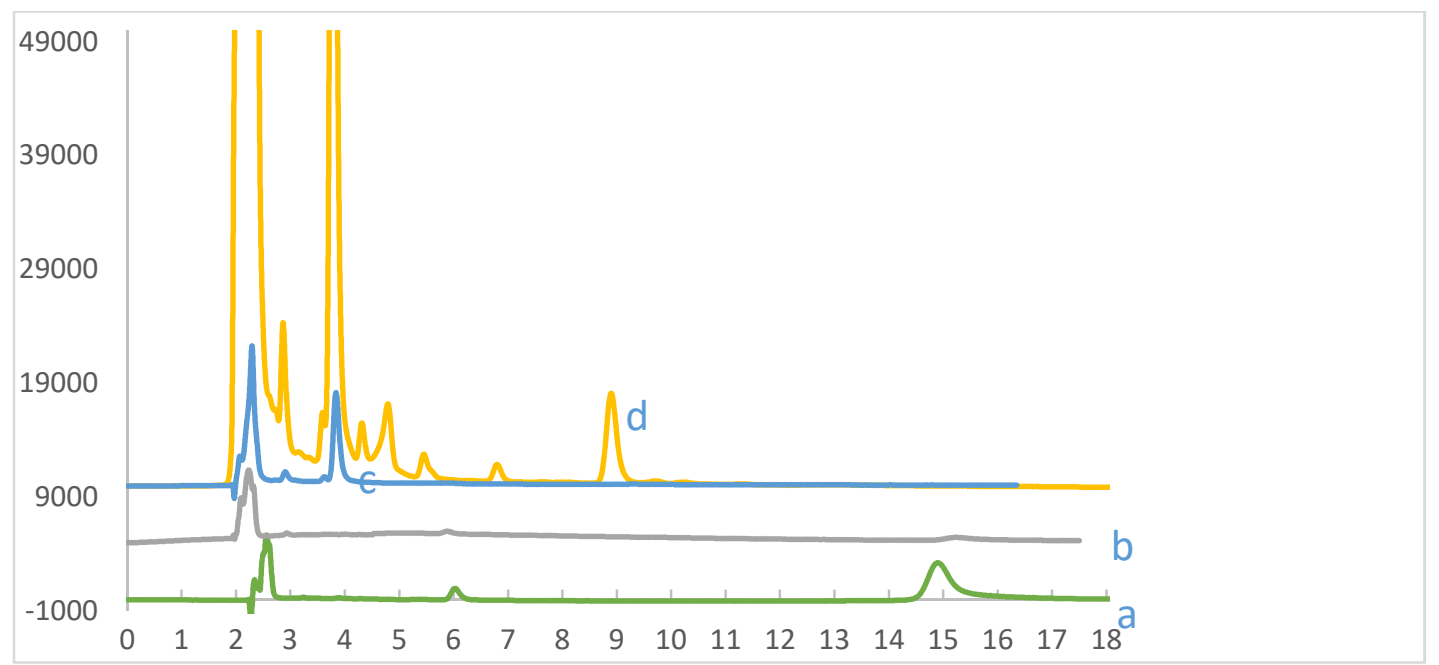

Figure 8. HPLC chromatogram of aqueous solutions in equilibrium with ARS at $\mathrm{pH}$ 2.0. (a) ARS at $\mathrm{pH}$ 2 (green), (b) Wool loaded with ARS (grey), (c) ARS + Cr(VI) without wool (blue), (d) wool loaded with ARS after adsorption of $\mathrm{Cr}(\mathrm{VI})$ (yellow). Initial [ARS] $=1.0 \mathrm{mg} / \mathrm{L}, \mathrm{pH}=2.0$; contact time $120 \mathrm{~h}, \mathrm{~T}=$ $25.0^{\circ} \mathrm{C}$, shaking speed $=175 \mathrm{rpm}$. Mobile phase is $40 \%$ methanol and $60 \%$ phosphate buffer, flow rate $=1.5 \mathrm{~mL} / \mathrm{min}$.

High performance liquid chromatography (HPLC) was used to analyse solutions in contact with wool, ARS or both, in presence or absence of $\mathrm{Cr}(\mathrm{VI})$. In Figure 8a (green), the ARS peak appears at 15 min retention time. Upon removal by wool, this peak disappears, due to ARS adsorption by wool (Figure $8 \mathrm{~b}$ (grey)). This peak also disappears upon mixing $\mathrm{Cr}(\mathrm{VI})$ with ARS in solution without wool, a process that results in the appearance of a new peak at 4 min retention time, among other low intensity peaks that are not apparent in this chromatogram at this scale (Figure 8c (blue)). However, exposing wool loaded with ARS to $\mathrm{Cr}(\mathrm{VI})$ causes not only the disappearance of ARS peak at $15 \mathrm{~min}$, but also the appearance of otherwise low intensity peaks in ARS-Cr(VI) without wool (Figure 8c) at retention times of 4.0, 4.4, 4.7, 5.5, 6.9 and $9.0 \mathrm{~min}$ (Figure $8 \mathrm{~d}$ (yellow). These peaks indicate that the mechanism of ARS oxidation on wool is similar to that in aqueous solution. These peaks have been attributed to a variety of oxidation by-products $[34,35]$. Thus adsorption of $\mathrm{Cr}(\mathrm{VI})$ by wool loaded with ARS results in ARS oxidation with simultaneous release of oxidation by-products to solution. This process frees and regenerates wool from ARS for reuse.

\subsubsection{Optimization Studies on $\mathrm{Cr}(\mathrm{VI})$ Removal by Wool Loaded with ARS}

\section{Effect of Contact Time}

Figure 9 shows the effect of contact time on $\mathrm{Cr}(\mathrm{VI})$ removal by wool loaded with ARS. Equilibrium removal is reached after $40 \mathrm{~min}$. This can be compared with the 90 min needed for removal of ARS alone (Figure 3). However, in a previous study, the optimum time for removal of $\mathrm{Cr}(\mathrm{VI})$ by free wool under short term conditions was $60 \mathrm{~min}$ [31]. Hence, adsorption is speeded by the presence of ARS on wool. 


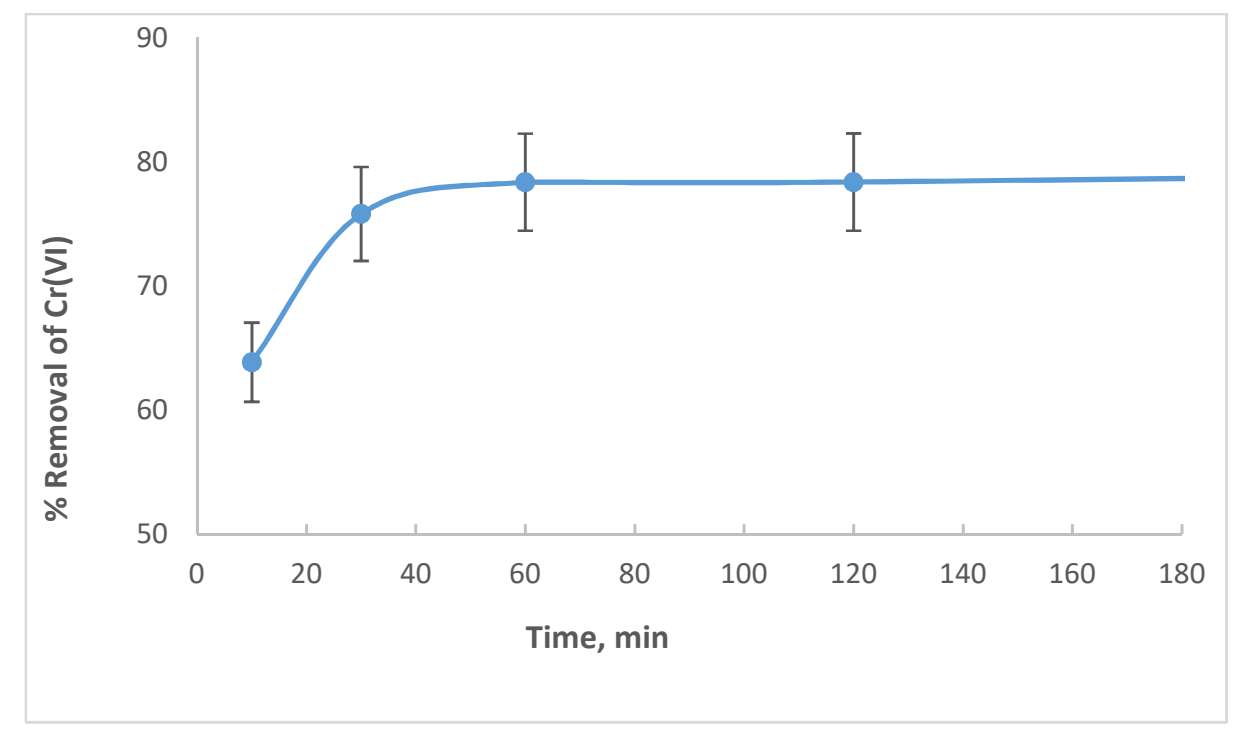

Figure 9. Effect of contact time on $\mathrm{Cr}(\mathrm{VI})$ removal by wool loaded with ARS. Initial [Cr(VI)] concentration is $100 \mathrm{mg} / \mathrm{L}$, adsorbent dosage $=8.0 \mathrm{~g} / \mathrm{L}, \mathrm{pH}=6.0, \mathrm{~T}=25.0^{\circ} \mathrm{C}$, shaking speed $=175 \mathrm{rpm}$.

Effect of $\mathrm{pH}$

$\mathrm{pH}$ is an important factor that controls uptake of $\mathrm{Cr}(\mathrm{VI})$. Figure 10 reveals that removal of $\mathrm{Cr}(\mathrm{VI})$ by wool loaded with ARS reaches a maximum of $77.8 \%$ at $\mathrm{pH} 2.0$, and remains almost constant at higher $\mathrm{pH}$. In previous studies [39-41], the optimum $\mathrm{pH}$ for $\mathrm{Cr}(\mathrm{VI})$ removal by free wool was 2.0, indicating that reduction of $\mathrm{Cr}(\mathrm{VI})$ is catalyzed by hydrogen ions. In this study, removal of $\mathrm{Cr}(\mathrm{VI})$ by wool loaded with ARS is essentially independent of $\mathrm{pH}$. $\mathrm{pH} 2.0$ was selected as optimum for removal of $\mathrm{Cr}(\mathrm{VI})$ by wool loaded with ARS.

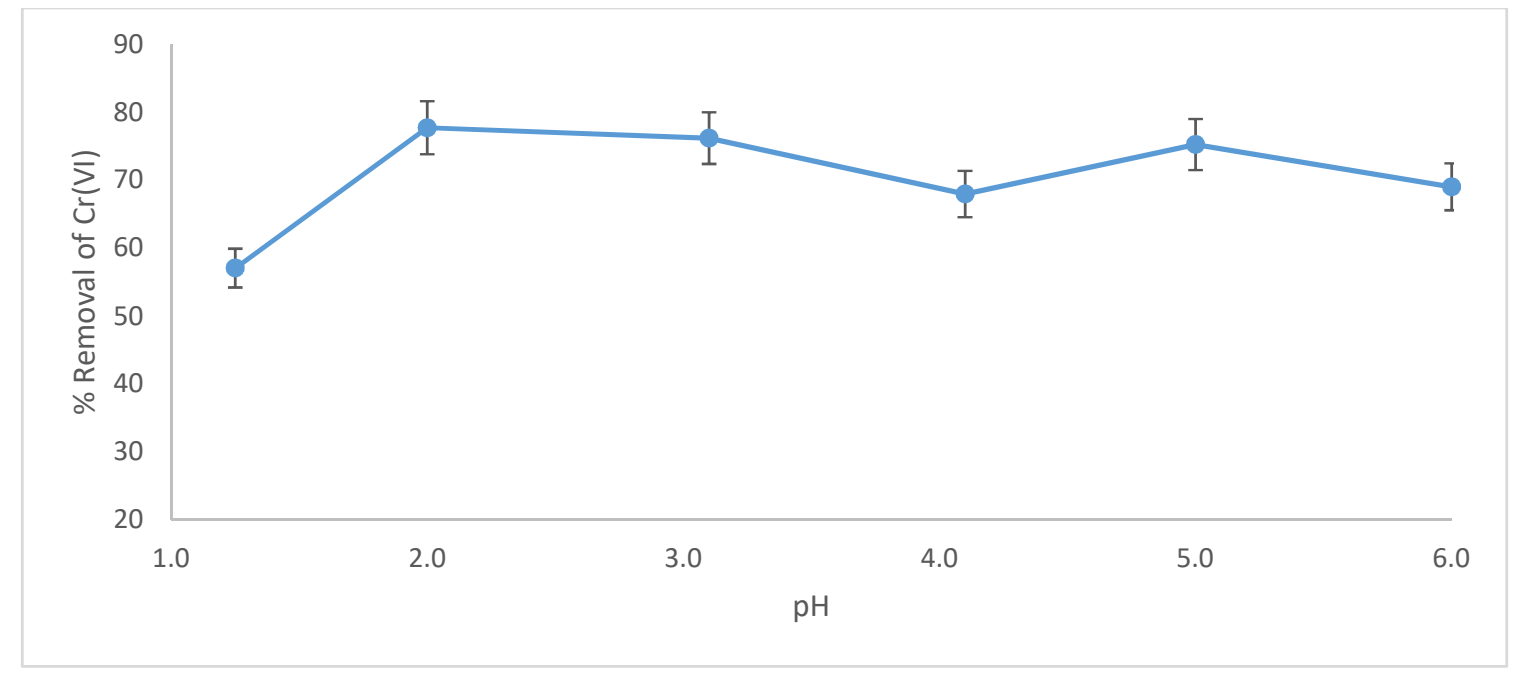

Figure 10. Effect of $\mathrm{pH}$ on removal of $\mathrm{Cr}(\mathrm{VI})$ by wool loaded with ARS. Initial $[\mathrm{Cr}(\mathrm{VI})]$ concentration = $100 \mathrm{mg} / \mathrm{L}$, adsorbent dosage $=8.0 \mathrm{~g} / \mathrm{L}$, contact time $=120 \mathrm{~min} ., \mathrm{T}=25.0^{\circ} \mathrm{C}$, shaking speed $=175 \mathrm{rpm}$.

\section{Effect of Adsorbent Dosage}

The removal of $\mathrm{Cr}(\mathrm{VI})$ by wool loaded with ARS was studied at several adsorbent dosages (Figure 11). As the dosage increases, $\mathrm{Cr}(\mathrm{VI})$ removal increases until it reaches ca. $90.3 \%$, at a dosage of $10.0 \mathrm{~g} / \mathrm{L}$. This is due to the increase of free active sites on wool and the increase in the number of sites loaded with ARS. 


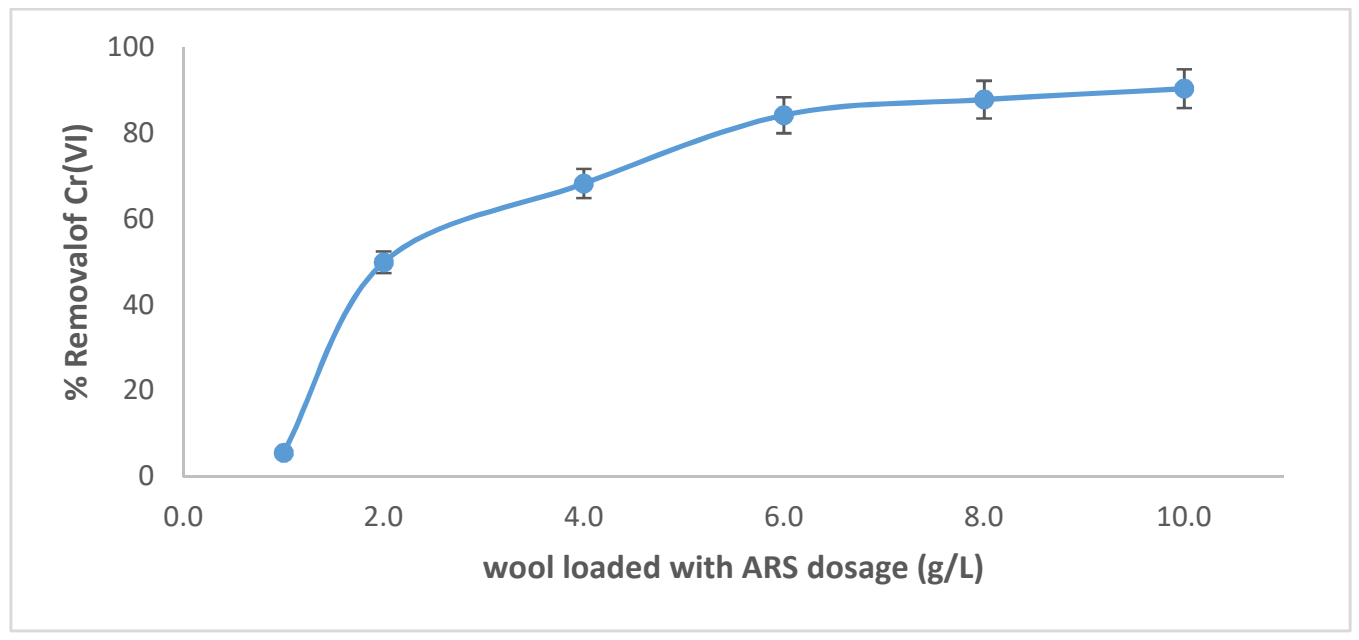

Figure 11. Effect of adsorbent dosage on removal of $\mathrm{Cr}(\mathrm{VI})$ by wool loaded with ARS. Initial [Cr(VI)] concentration $=100 \mathrm{mg} / \mathrm{L}, \mathrm{pH}=2.0, \mathrm{~T}=25.0^{\circ} \mathrm{C}$, contact time $=120 \mathrm{~min}$, shaking speed $=175 \mathrm{rpm}$.

\section{Effect of Temperature}

Figure 12 shows the effect of temperature on removal of $\mathrm{Cr}(\mathrm{VI})$ by wool loaded with ARS. At constant temperature, removal varies with initial concentration in a semi-random trend. It increases as the initial concentration rises from 25 to $100 \mathrm{mg} / \mathrm{L}$, then drops at $200 \mathrm{mg} / \mathrm{L}$. The expectation is that removal ought to decrease with increasing initial concentration. The opposing trends within the two simultaneous processes that accompany removal may explain this apparent anomaly. The first is the adsorption of $\mathrm{Cr}(\mathrm{VI})$ by free sites on wool and the second is the oxidation of ARS by $\mathrm{Cr}(\mathrm{VI})$. In the first, removal decreases with increasing initial concentration, whereas in the second, the opposite effect is observed. Figure 12 also reveals that at constant initial $\mathrm{Cr}(\mathrm{VI})$ concentration, $\mathrm{Cr}(\mathrm{VI})$ removal decreases with increasing temperature. This observation indicates that the principal adsorption step is exothermic.

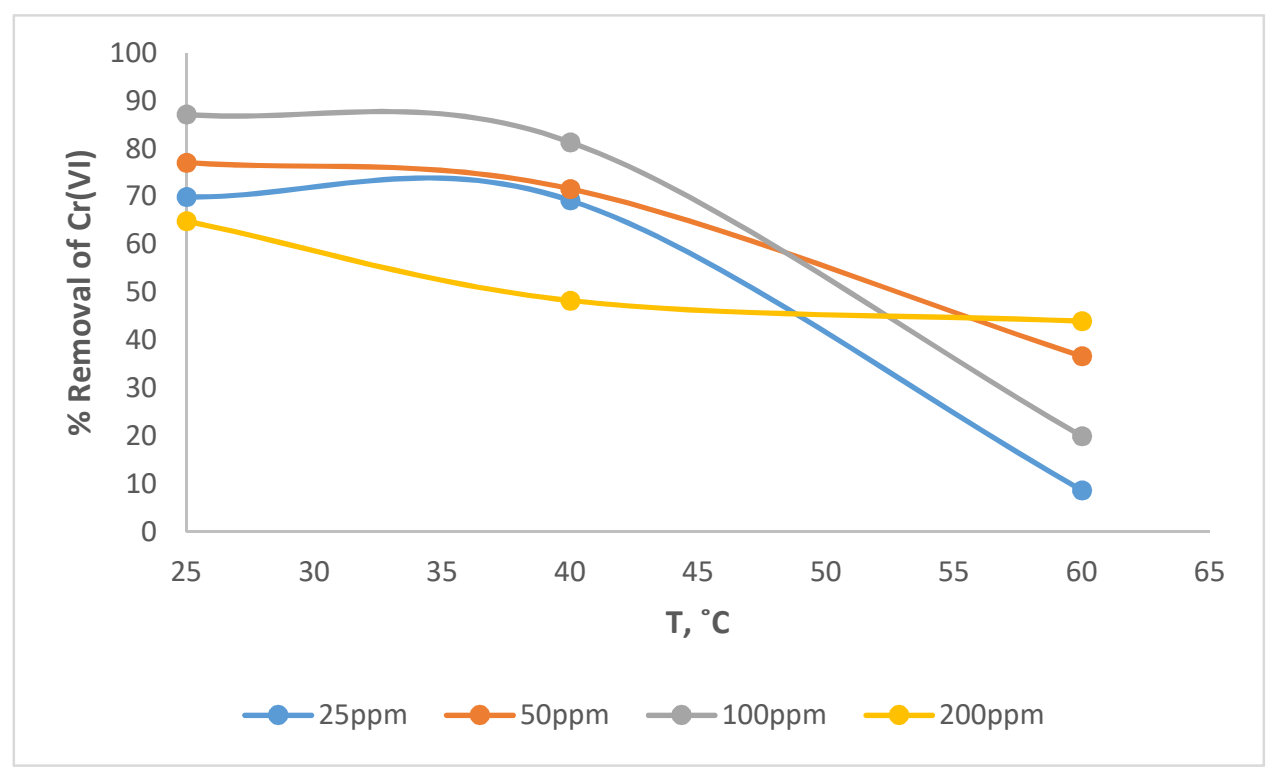

Figure 12. Effect of temperature and $\mathrm{Cr}(\mathrm{VI})$ concentration on removal of $\mathrm{Cr}(\mathrm{VI})$ by wool loaded with ARS. Adsorbent dosage $=8.0 \mathrm{~g} / \mathrm{L}, \mathrm{pH}=2.0$, contact time $=120 \mathrm{~min}$, shaking speed $=175 \mathrm{rpm}$. 


\subsection{Adsorption Mechanism}

Based on the above results, Figure 13 shows a proposed two-step mechanism for removal of $\mathrm{Cr}(\mathrm{VI})$ by wool loaded with ARS (ARS-W). The second step is similar to that proposed in previous reports for removal of $\mathrm{Cr}(\mathrm{VI})$ by other natural adsorbents, but with ARS yielding oxidation products $[39,41]$.

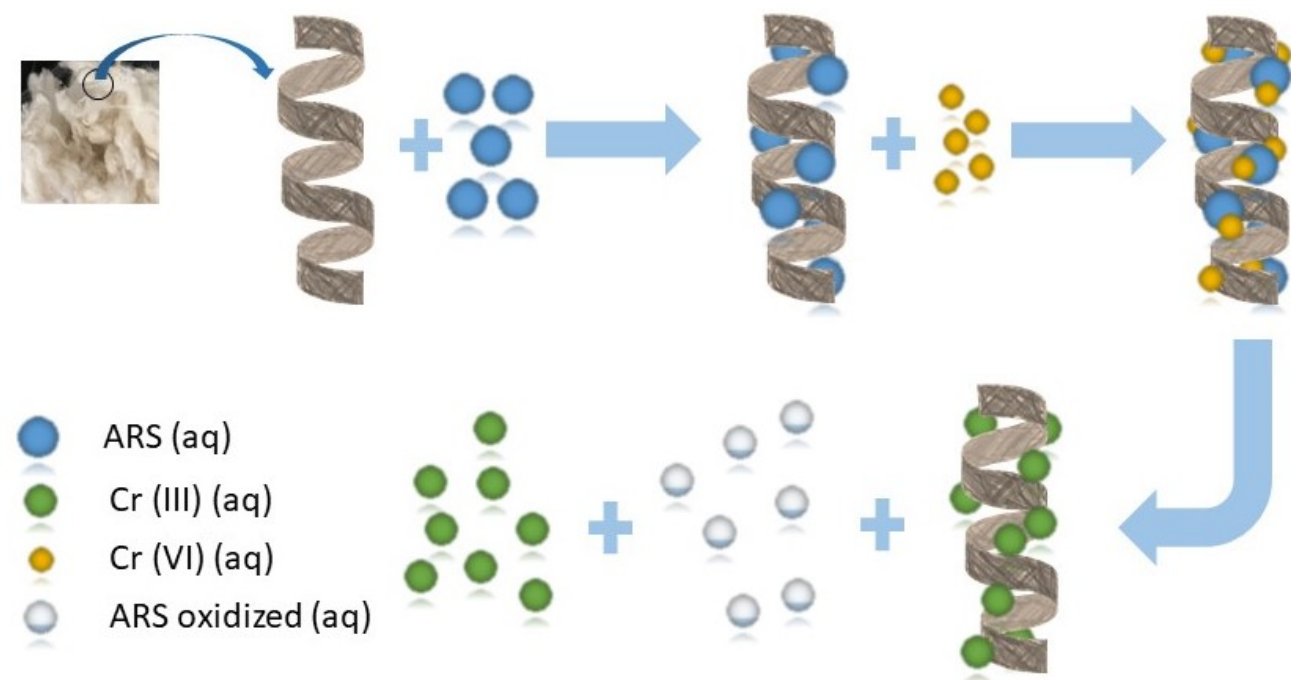

Figure 13. Proposed mechanism for removal of $\mathrm{Cr}(\mathrm{VI})$ by wool loaded with ARS.

\subsection{Isotherm Analysis}

Adsorption data were fitted to both the Langmuir and Freundlich models. Figure 14 shows the dependence of adsorption capacity on $\mathrm{Cr}(\mathrm{VI})$ concentration after a $120 \mathrm{~min}$ contact, using wool loaded with ARS as adsorbent. The dependence does not resemble any known adsorption behavior, indicating that equilibrium was not achieved within this time. This is because removal by adsorption is followed by a time dependent redox process. Hence, the isotherm could not be fitted to any of the models that predicate equilibrium between adsorbate and adsorbent.

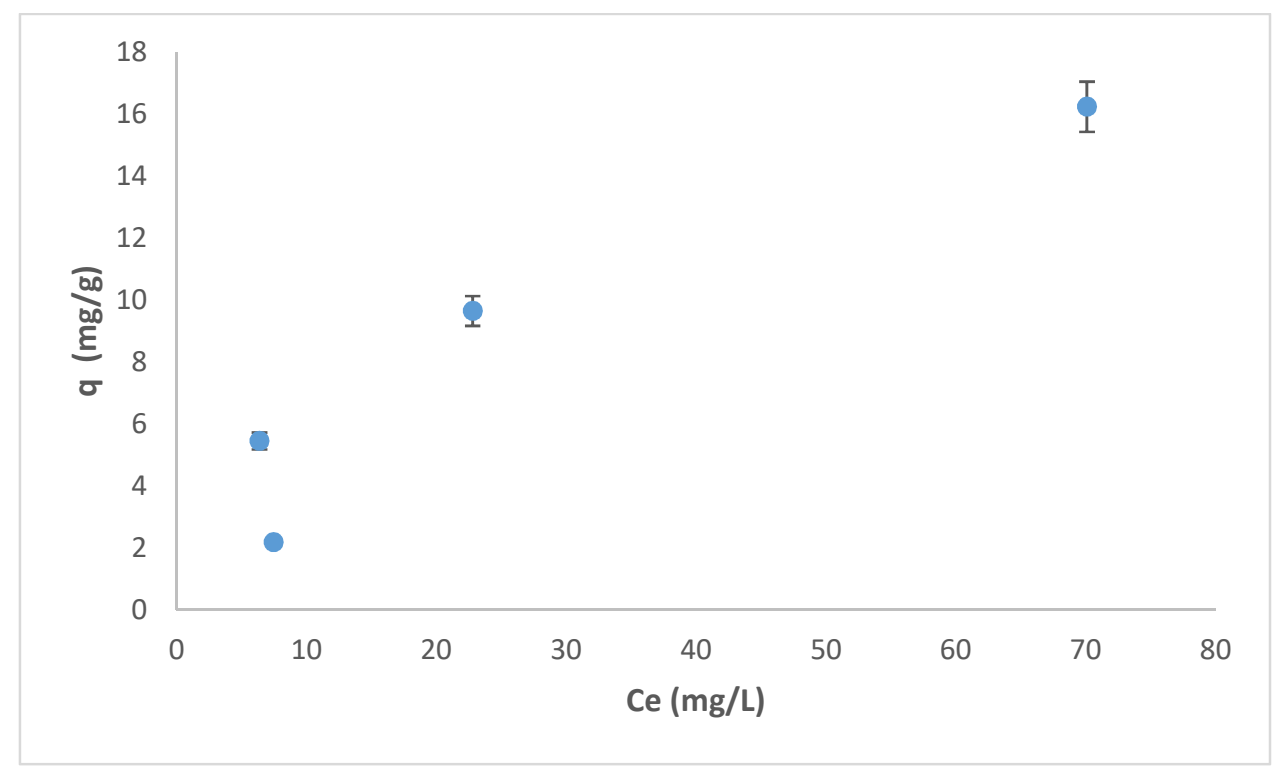

Figure 14. Adsorption capacity $(\mathrm{q})$ for the removal of $\mathrm{Cr}(\mathrm{VI})$ by wool loaded with ARS as function of $\mathrm{Cr}(\mathrm{VI})$ concentration. Contact time $=120 \mathrm{~min}$, adsorbent dosage $=8.0 \mathrm{~g} / \mathrm{L}, \mathrm{pH}=2.0, \mathrm{~T}=25.0^{\circ} \mathrm{C}$, shaking speed $=175 \mathrm{rpm}$. 


\subsection{Regeneration Studies}

Wool loaded with ARS has been used to investigate its regeneration by the simultaneous removal and reduction of $\mathrm{Cr}(\mathrm{VI})$ from industrial wastewater, followed by ARS oxidation. For this purpose, wool loaded with ARS was prepared by shaking wool with $100 \mathrm{mg} / \mathrm{L} \mathrm{ARS} \mathrm{solution} \mathrm{at} \mathrm{optimum}$ conditions. The resulting wool-ARS was washed with DDW and dried. Spectrophotometric analysis of the equilibrium solution gave ARS removal of 93.2\%. Wool-ARS was then shaken with $50 \mathrm{mg} / \mathrm{L}$ $\mathrm{Cr}(\mathrm{VI})$ solution at optimum conditions for 4 days. Wool-ARS-Cr was washed with DDW and dried for further studies. AAS analysis of the equilibrium solution gave $86.8 \% \mathrm{Cr}(\mathrm{VI})$ removal. The cycle was repeated four times. Figure 15 shows removal of ARS and $\mathrm{Cr}$ (VI) after each cycle. Removal of both ARS and Cr(VI) by wool varies in the range $60 \%-90 \%$, even at the end of the fourth cycle. This finding suggests promising prospects for using a sequential batch reactor for the simultaneous removal of organic pollutants and $\mathrm{Cr}(\mathrm{VI})$, which is self-regenerated under field conditions.

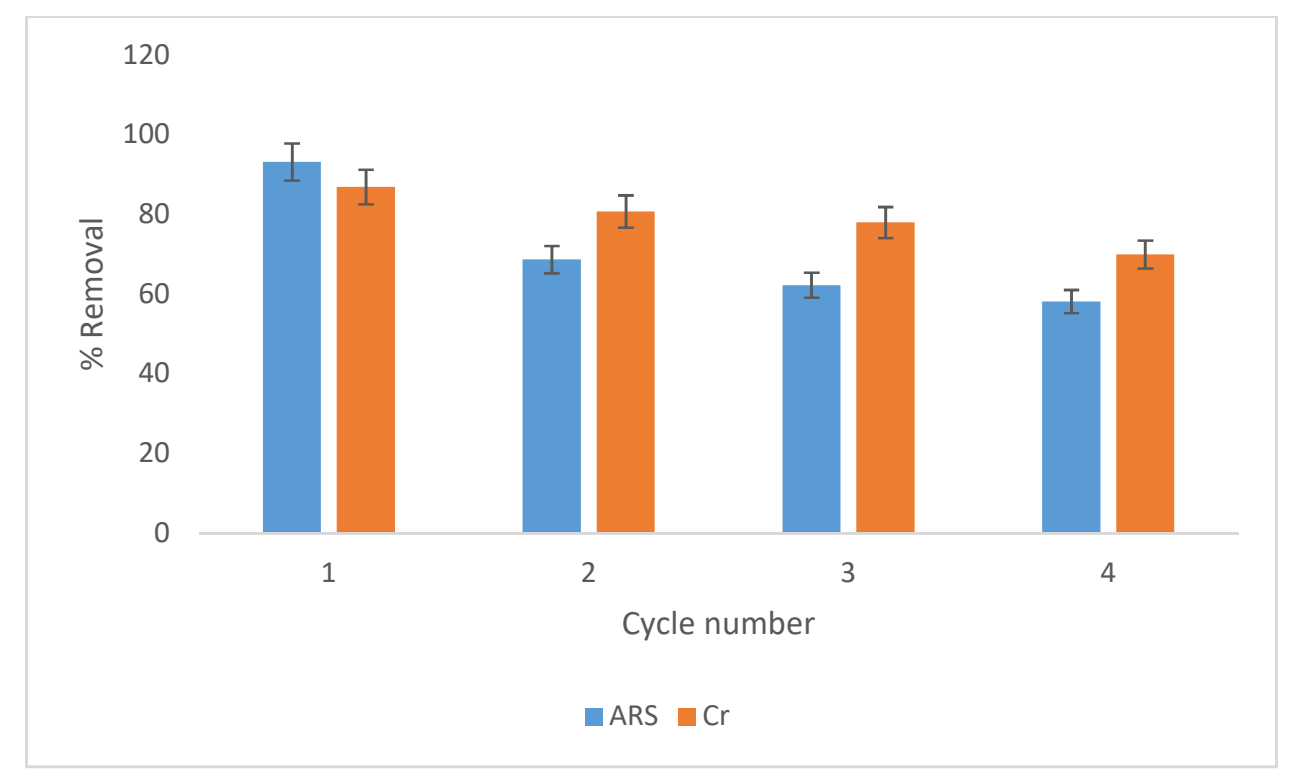

Figure 15. Effect of different cycles on removal of $\mathrm{Cr}(\mathrm{VI})$ and $\mathrm{ARS}$ by wool. Adsorbent. dosage = $8.0 \mathrm{~g} / \mathrm{L}, \mathrm{pH}=2.0, \mathrm{~T}=25.0^{\circ} \mathrm{C}$, shaking speed $=175 \mathrm{rpm}$.

\section{Conclusions}

Removal efficiency of ARS by wool depends on contact time, adsorbent dosage, initial ARS concentration and $\mathrm{pH}$. At $25.0^{\circ} \mathrm{C}$, The Freundlich adsorption isotherm gave a good fit to the adsorption data. ARS undergoes slow oxidization by $\mathrm{Cr}(\mathrm{VI})$ at $\mathrm{pH}$ 2.0. This oxidation and the ability of wool to adsorb $\mathrm{Cr}(\mathrm{VI})$ combine to form the basis of an effective method for sequential removal of ARS and $\mathrm{Cr}(\mathrm{VI})$, resulting in partial self-regeneration of wool from ARS. Wool loaded with ARS was efficient in removing $\mathrm{Cr}(\mathrm{VI})$ with the simultaneous appearance of oxidation ARS by-products. A sequential batch reactor, designed for four cycles, indicated no significant reduction in the ability of wool to remove ARS, followed by $\mathrm{Cr}(\mathrm{VI})$. A two-step mechanism for this removal has been proposed. The first involves fast adsorption of $\mathrm{Cr}(\mathrm{VI})$ on wool loaded with ARS, and the second involves an oxidation of ARS, followed by desorption of oxidation by-products into solution. Several of these by-products were detected by HPLC. The surface of wool before and after adsorption of ARS, followed by the adsorption of $\mathrm{Cr}(\mathrm{VI})$, which was characterized by FTIR. The results support the suggested mechanism. These findings form a basis for the design of batch sequential reactor for removal of ARS and $\mathrm{Cr}(\mathrm{VI})$, under field conditions and with zero liquid discharge. 
Author Contributions: Z.A.S. and B.A.A. performed most of the experiments. This research was led by T.H.I., M.I.K. and F.H.J. were instrumental in the initiation, conceptualization and planning of this work. All authors have read and agreed to the published version of the manuscript.

Funding: This research was supported by the American University of Sharjah under grant number FRG17-R-17.

Conflicts of Interest: The authors declare no conflict of interest.

\section{References}

1. Zazo, J.A.; Paull, J.S.; Jaffe, P.R. Influence of plants on the reduction of hexavalent chromium in wetland sediments. Environ. Pollut. 2008, 156, 29-35. [CrossRef] [PubMed]

2. Yang, R.; Wang, Y.; Li, M. A new carbon/ferrous sulfide/iron composite prepared by an in situ carbonization reduction method from hemp (Cannabis sativa $\mathrm{L}$ ) stems and its $\mathrm{Cr}(\mathrm{VI})$ removal ability. ACS Sustain. Chem. Eng. 2014, 2, 1270-1279. [CrossRef]

3. Sumathi, K.; Mahimairaja, S.; Naidu, R. Use of low-cost biological wastes and vermiculite for removal of chromium from tannery effluent. Bioresour. Technol. 2005, 96, 309-316. [CrossRef] [PubMed]

4. Yang, A.; Zhai, X. Degradation of nitrobenzene by nano-TiO2 catalyzed ozonation. J. Mol. Catal. A Chem. 2007, 267, 41-48. [CrossRef]

5. Huang, Y.; Wang, X. Applications of conjugated polymer based composites in wastewater purification. RSC Adv. 2014, 4, 62160-62178. [CrossRef]

6. Gholivand, M.; Yamini, Y.; Dayeni, M. Adsorptive removal of alizarin red-S and alizarin yellow GG from aqueous solutions using polypyrrole-coated magnetic nanoparticles. J. Environ. Chem. Eng. 2015, 3, 529-540. [CrossRef]

7. Brown, D. Effect of colorants on the aquatic environment. Ecotox. Environ. Safe 1987, 13, 139-147. [CrossRef]

8. Ding, F.; Sun, Y. Characterization of alizarin red $\mathrm{S}$ binding sites and structural changes on human serum albumin: A biophysical study. J. Hazard. Mater. 2011, 186, 352-359. [CrossRef]

9. Ghaedi, M.; Hassanzadeh, A.; Nasiri, S.N. Multiwalled carbon nanotubes as adsorbents for the kinetic and equilibrium study of the removal of alizarin red S and morin. J. Chem. Eng. Data 2011, 5, 2511-2520. [CrossRef]

10. Golder, A.K.; Hridaya, N.; Samanta, A.N. Electrocoagulation of methylene blue and eosin yellowish using mild steel electrodes. J. Hazard. Mater. 2005, 127, 134-140. [CrossRef]

11. Tuzen, M.; Saygi, K.O.; Usta, C. Pseudomonas aeruginosa immobilized multiwalled carbon nanotubes as biosorbent for heavy metal ions. Bioresour. Technol. 2008, 99, 1563-1570. [CrossRef] [PubMed]

12. Duran, A.; Tuzen, M.; Soylak, M. Preconcentration of some trace elements via using multiwalled carbon nanotubes as solid phase extraction adsorbent. J. Hazard. Mater. 2009, 169, 466-471. [CrossRef]

13. Chowdhury, T.; Zhang, L.; Zhang, J. Removal of arsenic(III) from aqueous solution using metal organic framework-graphene oxide nanocomposite. J. Nanomater. 2018, 8, 1062. [CrossRef] [PubMed]

14. Gautam, R.; Mudhoo, A.; Chattopadhyaya, M. Kinetic, equilibrium thermodynamic studies and spectroscopic analysis of alizarin red S removal by mustard husk. J. Environ. Chem. Eng. 2013, 1, 1283-1291. [CrossRef]

15. Yang, J.Y.; Jiang, X.Y.; Jiao, F.P. The oxygen-rich pentaerythritol modified multi-walled carbonnanotube as an efficient adsorbent for aqueous removal of alizarin yellow R and alizarin red S. Appl. Surf. Sci. 2018, 436, 198-206. [CrossRef]

16. Rehman, R.; Mahmud, T.; Anwar, J. Removal of alizarin red S (dye) from aqueous media by using alumina as an adsorbent. J. Chem. Soc. Pak. 2011, 33, 228-232.

17. Ghadia, M.; Najibi, A.; Hossaininian, H.; Shokrollahi, A.; Sylak, M. Kinetic and equilibrium study of alizarin red S removal by activated carbon. Toxicol. Environ. Chem. 2012, 94, 40-48. [CrossRef]

18. Gautam, R.K.; Mudhoo, A.; Lofrano, G. Biomass-derived biosorbents for metal ions sequestration: Adsorbent modification and activation methods and adsorbent regeneration. J. Environ. Chem. Eng. 2014, 2, 239-259. [CrossRef]

19. Saha, R.; Nandi, R.; Saha, B. Sources and toxicity of hexavalent chromium. J. Coord. Chem. 2011, 64, $1782-1806$. [CrossRef]

20. Espinosa, D.; Tenório, J. Thermal behavior of chromium electroplating sludge. Waste Manag. 2001, 21, 405-410. [CrossRef] 
21. Barakat, M.A. New trends in removing heavy metals from industrial wastewater. Arab. J. Chem. 2011, 4, 361-377. [CrossRef]

22. Tchounwou, P.B.; Yedjou, C.G.; Patlolla, A.K. Heavy metals toxicity and the environment. EXS 2012, 101, 133-164.

23. Bartlett, L.; Vesilind, P.A. Chemistry and controversy: The regulation of environmental chromium. Environ. Eng. Policy 1998, 1, 81-86. [CrossRef]

24. Fendorf, S.; Wielinga, B.W.; Hansel, C.M. Chromium transformations in natural environments: The role of biological and abiological processes in chromium(VI) reduction. Int. Geol. Rev. 2000, 4, 691-701. [CrossRef]

25. Costa, M. Potential hazards of hexavalent chromate in our drinking water. Toxicol. Appl. Pharmacol. 2003, 188, 1-5. [CrossRef]

26. Yang, J.; Yu, M.; Qiu, T. Adsorption thermodynamics and kinetics of Cr(VI) on KIP210 resin. J. Ind. Eng. Chem. 2014, 20, 480-486. [CrossRef]

27. Yadav, S.; Srivastava, V.; Banerjee, S. Adsorption characteristics of modified sand for the removal of hexavalent chromium ions from aqueous solutions: Kinetic, thermodynamic and equilibrium studies. Catena 2013, 100, 120-127. [CrossRef]

28. Li, Y.; Gao, B.; Wu, T. Hexavalent chromium removal from aqueous solution by adsorption on aluminum magnesium mixed hydroxide. Water Res. 2009, 43, 3067-3075. [CrossRef]

29. Chang, Y.; Lim, J.; Yang, J.K. Removal of $\mathrm{As}(\mathrm{V})$ and $\mathrm{Cr}(\mathrm{VI})$ in aqueous solution by sand media simultaneously coated with Fe and Mn oxides. J. Ind. Eng. Chem. 2012, 18, 188-192. [CrossRef]

30. Mahmoud, M.E.; Yakout, A.A.; Abdel-Aal, H. Speciation and selective biosorption of $\mathrm{Cr}(\mathrm{III})$ and $\mathrm{Cr}(\mathrm{VI}) \mathrm{using}$ nanosilica immobilized-fungi biosorbents. J. Environ. Eng. ASCE 2015, 141, 131-139. [CrossRef]

31. Jumean, F.; Khamis, M.; Sara, Z. Concurrent removal and reduction of $\mathrm{Cr}(\mathrm{VI})$ by wool: Short and long term equilibration studies. Am. J. Anal. Chem. 2015, 6, 47-57. [CrossRef]

32. Ray, P.; Sabri, M.; Ibrahim, H. Design and optimization of a batch sequential contactor for the removal of chromium(VI) from industrial wastewater using sheep wool as low cost adsorbent. Deswater 2018, 113, 109-113. [CrossRef]

33. Ortiz, E.; Solis, H.; Noreña, L. Degradation of red anthraquinone dyes: Alizarin, alizarin $S$ and alizarin complexone by ozonation. Int. J. Environ. Sci. Dev. 2017, 8, 255-259. [CrossRef]

34. Asha, P.; Narayanamurthy, P.; Kavya, M.S. Kinetics and mechanism of oxidation of alizarin red-S using chloramine-T in acid medium. Int. J. Environ. Sci. Dev. 2016, 3, 2394-9333.

35. Bishop, E. Indicators, 1st ed.; Pergamon: Oxford, UK, 1972; p. 250.

36. Dada, A.; Olalekan, A.; Olatunya, A. Langmuir, Freundlich, Temkin and Dubinin-Radushkevich isotherms studies of equilibrium sorption of $\mathrm{Zn}^{2+}$ unto phosphoric acid modified rice husk. J. Appl. Chem. 2012, 3, $38-45$.

37. Tan, L.A.; Hameed, B.H. Adsorption isotherms, kinetics, thermodynamics and desorption studies of basic dye on activated carbon derived from oil palm empty fruit bunch. J. Appl. Sci. 2010, 10, 2565-2571. [CrossRef]

38. Hameed, B.H.; Mahmoud, D.K.; Ahmad, A.L. Equilibrium modeling and kinetic studies on the adsorption of basic dye by a low-cost adsorbent: Coconut (cocosnucifera) bunch waste. J. Hazard. Mater. 2008, 158, 65-72. [CrossRef] [PubMed]

39. Manassra, A.; Khamis, M.; Ihmied, T.; Eldakiky, M. Removal of chromium by continuous flow using wool packed columns. Electron. J. Environ. Agric. Food Chem. 2010, 9, 651-663.

40. EPA Method. Chromium Hexavalent (Colorimetric). Educ. Publ. Awards (EPAA) 1992, 7196A, 1-6.

41. Fiol, N.; Escudero, C.; Villaescusa, I. Chromium sorption and $\mathrm{Cr}(\mathrm{VI})$ reduction to $\mathrm{Cr}(\mathrm{III})$ by grape stalks and yohimbe Bark. Bioresour. Technol. 2008, 99, 5030-5036. [CrossRef]

(C) 2020 by the authors. Licensee MDPI, Basel, Switzerland. This article is an open access article distributed under the terms and conditions of the Creative Commons Attribution (CC BY) license (http://creativecommons.org/licenses/by/4.0/). 